\title{
A Study on Public-Private Partnerships with reference to Municipality of Korca, Albania
}

\author{
Eva Dhimitri
}

PhD, Faculty of Economy, University Fan S. Noli, Korca, Albania

\begin{abstract}
.
Public private partnership is in central of good governance with emphasis on efficiency, inclusion and partnership. The main point is that the partnership does not mean competition, but cooperation between different organizations. It means a formal link between public and private sectors and involves cooperation in planning, financing and implementation of joint projects to achieve common goals. The state assists in its mission from many actors, and above all from the private sector. This article aims to explore the concept of Public Private Partnership as an approach that provides mutual benefits to both public and private sectors. Albania has great potential to develop successful forms of Public Private Partnerships and the public interest is quite high, however, it is important to learn from own successful and not successful experiences of the past, as well as from the experience of the others. This study focused in experience of Municipality of Korca, main region in southeast of Albania.
\end{abstract}

Keywords: Public- Private Partnership; local government; good governance; social projects; efficiency.

\section{Introduction.}

Changes at the present time are characterized by dynamism, speed and complexity, therefore the public sector, local governments are actively under these rapid changes in socio-economic context. Today the modern state should act as a promoter of strategic, economic and social development. Main objectives of public authorities can be summarized as follows: To protect the public interest and undertaking the regulatory acts in those areas where the market is not functioning properly; to planning and to manage the implementation of public policies; to create an enabling environment to encourage entrepreneurship and investment. Public private partnership (PPP or P3) is central to good governance with emphasis on efficiency and involvement or partnership. Old regulatory role of the state changed. Now the new role of the state is partner aimed development. This is a cultural change that is characterized by mutual trust between the public and private sectors, as well as a greater economic understanding by the government on the one hand, and a stronger orientation towards a common goal of private enterprises, on the other. Public-Private Partnerships are widely accepted and recognized in public sector management. It is the new mentality in Albanian society. On one hand, public institutions have made efforts to adopt advanced models of development, have undertaken reforms and are all-reformed itself, have approximated with EU legislation, have made efforts to implement, have decentralized the responsibilities from central government to local governments. On the other hand, private business has demonstrated progress in increasing the business contribution to local GDP; they have begun to improve the level of management, have advanced the institutionalization of business representation and its perfection by European standards. In the same time civil society is represented by a consolidated network of non-profit organizations growing in national and local level. The purpose of this study is to identify the values of solidarity, the obligation of individuals to contribute to solving community problems. Local actors have begun dialogue on issues of common interest, but rarely noticed premise that goes against the principle of dialogue and partnership in development.

\section{Literature Review.}

Public Private Partnerships are defined as a form of collaboration between public and private sector, taking different legal forms and being implemented in several sectors. There is a wide spread of these types of partnerships, different literature acknowledge that there is not a clear definition of such a partnership. From the 1980s, the key words of the New Public Management were privatization, market mechanism, the distribution of public goods and services, competitiveness and 
reinventing the role of government. The aims of New Public Management were: reduction of public sector expenditure, delegation of responsibilities to the private sector and promotion of voluntary commitment of private sector to providing public goods (Mitchell-Weaver; Manning 1991). In a competitive global environment, governments around the world were focusing on new ways to finance projects, build infrastructure and deliver services. Initially, most public-private partnerships were negotiated individually, as one-off deals, and much of this activity began in the early 1990s. The 1990s saw the creation of PPPs as the main means of public policies worldwide (Osborne 2000, p.1), as a novelty of the New Public Management. The principles of New Public Management encouraged the establishment of Public-Private Partnership as a new management tool. Nowadays there is a large variety of public-private partnership definitions worldwide. The European Commission (2004) defines PPPs as "forms of cooperation between public authorities and the world of business which aim to ensure the funding, construction, renovation, management or maintenance of an infrastructure or the provision of a service" OECD (2008) defines PPP as "an arrangement between the government and one or more private partners (which may include the operators and the financers) according to which the private partners deliver the service in such a manner that the service delivery objectives of the government are aligned with the profit objectives of the private partners, and where the effectiveness of the alignment depends on a sufficient transfer of risk to the private partners".

\section{Methodology.}

This is a conceptual study with explorative methodology. The preparation of this article is based on secondary research, primarily in the form of literature review. The secondary data was collected from different sources like text books, research papers, articles, reports, surveys, strategic documents. This study was made to have an insight of Public Private Partnerships with reference to Municipality of Korca's projects and to analyses difficulties and benefits. This article aims to raise attention not only to the benefits of PPPs through exploring the trends of development, pointing out successful cases, but also to the need of properly understanding the concept of PPPs in order to reach successful agreements. These partnerships are considered to give a positive contribution not only to the economic development but also to the social welfare of a region.

\section{Why is necessary the Public Private Partnership?}

In this way, we can group the causes for the development of PPPs in economic and social reasons; the former are further classified into macroeconomic factors related to the availability of public and secondly microeconomic investment related to the efficiency of public investment. In general, public authorities can consider PPP arrangements in any of the following circumstances. When:

- The project cannot be provided with the financial resources or expertise of the public sector alone;

- A private partner would increase the quality or level of service over that provided by the public sector on its own;

- $\quad$ A private partner would allow the project to be implemented sooner than if only the public sector was involved;

- $\quad$ There is support from users for the involvement of a private partner;

- There is an opportunity for competition among prospective private partners;

- There are no regulatory or legislative prohibitions to involving a private partner in the provision of a project;

- The cost of the project can be recovered through the implementation of user fees;

- $\quad$ The project provides an opportunity for innovation;

- $\quad$ There is a track record of partnerships between government and the private sector;

- There are opportunities to foster economic development.

The public sector is importing private initiatives, knowledge, skills and experience, but at the same time maintaining responsibility, democratic control, policy-making and protecting the public's interests. At the strategic level, arguments can be raised that the public sector is striving to increase efficiency through the use of business methods and entrepreneurial know-how, but private companies are interested in sharing their approach as a way to gain competitive advantage. Private partners receive new contracts, experience and at the same time expand their network, employ their people, use technological innovations. It is also in the interest of the private and public sector to gain access to public policy when co- 
operating and co-participating. When we talk about PPP at the same time we have also highlighted its advantages. In addition to alleviating pressure on public finances and helping to allocate them to other indispensable places, there are also some other useful advantages to be mentioned. In the context of PPP, the risks are transferred to the private sector, involving private sector know-how; the private sector takes an active part in public policy, cost transparency is high, services are cheaper and more qualitative, etc. Public-Private Partnerships can provide innovative and competitive solutions for the same amount of committed money, risk is allocated to the partner who manages it better and mitigates or reduces it, and at the same time processes are open, fair and transparent.

\section{Experiences of Municipality of Korca}

Korca Municipality is the major urban centre in Southeast Albania. Korca Region neighbours the Elbasan Region to the Northwest, the Berat Region to the West, the Gjirokaster Region to the Southwest, while it shares borders with Macedonia to the Northeast and Greece to the Southeast. Currently Korca Municipality is working to implement some PPP with aim revitalization of some areas that are not functioning. Some of Korca Municipality initiatives are:

1. Establishment of a Public Private Partnership Center (PPP), as a study and coordination center in the function of local economic development. This center will identify various issues, coordinate the work of all actors to define project ideas and then draft project proposals to subsequently apply to potential donors to provide the necessary funding by monitoring the implementation of projects. It will become a center for different studies that precede the drafting of specific strategies or plans, concrete projects etc. The establishment of this center will also help to concretize the cooperation of local government, business and community in the interest of everyone. Expected results will be: Creating partnerships among stakeholders; identifying the real needs of economic development; drafting project proposals in a professional manner; finding potential funds for project implementation. Target groups are: Local community, businesses, local government institutions.

2. The PPP program for social housing and neighborhood improvement in the city of Korça. The main objective of this project is to improve local property management and attracting private sector investment with competition and transparency to rebuild urban lands, to provide housing and relevant services to the community. Completed of the project will offer affordable housing and social housing opportunities for some families that are unable to access market financial instruments. The project will include space for trading or for rent, open areas, parking and improvements necessary public infrastructure. This project was assisted by USAID project for Local Governance (LGPA) through its partner, the Urban Research Institute (URI). The project is expected to produce up to 463 apartments, of which $80 \%$ will be sold at the price of market and $20 \%$ will be subsidized for social housing. The project aims to general increase of living standards in a welldefined neighborhood community, while at the same time increasing the capacity of the municipality to influence private investment with through a Public Private Partnership structure (PPP). The main goals of the project are: to increase the value of public properties that are little used and owned municipality; to increase of the investment portfolio of the municipality in infrastructure and improving public services by developing skills for analyzing feasibility of the project and identifying appropriate alternatives for project financing; meeting the needs for social housing by investing in investments directly with the private sector through the PPP mechanism. The activities of this project will help the Municipality of Korça for overcoming problems in property management, evidencing the use it will maximize the proper and productive use of these properties, thus creating resources that can be used to increase the quality of public services provided by hall. Also, this project can help the municipality increase its experience and capacity local administration and elected officials in property management, treatment of issues such as local government property management, based on internationally accepted approaches. Enhance property management will enable it the municipality uses its assets more strategically to generate revenue necessary and to reduce the cost of providing the best public services. Identification of the correctness of the key parameters of the project will provide a competitive situation that will enable a transparent and quality assessment process for selecting the right private investor. The community also benefits from the processes as this is the right to benefit from one property (gained) and not given. As the final beneficiary of planning activities and municipal development programs, it is expected that a considerable number of families of registered as homeless in Korça will benefit from the realization of the proposed project public-private partnership. The private sector will benefit from the opportunity to compete in a fair and equitable way transparent for the right to build a major project with different uses in one an important city in Albania. The municipality will select the proposal it meets basic building parameters determined by the municipality, a project that is feasible and realist as a business venture and offering the greatest benefits or benefits to community. However, it is understood that the builder will also realize a fair profit as well the result of his involvement in this project. 
The most important achievement of this project is the introduction of public-private partnership as one an effective alternative to managing local properties by establishing a relationship long-term relationship between the private sector and the local government unit. Partnership structure private public establish a stable cooperation between the two parties by sharing risks, contribution capital, and profitability from the successful implementation of the project. In this way, two goals are achieved: This project is an important stage in starting a 10-year program housing designed by the Municipality of Korça, which aims to cut to $13 \%$ of the demand homeless families in the years to come. Today, Korça has about 1,500 homeless families out of it which 738 have reapplied for housing under Law 9232, dated 13.05.2004, "On the Program Social Security for Housing Citizens in Urban Areas ".

\section{Conclusions and recommendations.}

Public Private Partnerships are widely known to be the new face of development and growth where the collaboration between public and private actors aims to the achievement of common goals. PPPs have proven to be an effective approach in terms of providing investments and public services, in several European countries. Albania is a country with great potential for PPPs. Good PPPs should be built on basis of trust, mutual agreement, transparency and accountability. Some recommendations:

- $\quad$ Legal institutionalization of business relations / power central / local government and civil society. This should be accomplished through an open social dialogue.

- Extension of the tools of partnership with 'game rules' even at the local level. This relates to the transfer of some important powers from central government to local government, particularly fiscal powers.

- The important thing is to ensure greater transparency of public-private cooperation, which should also be provided for this law.

- $\quad$ Redefining the role of the state as the creator of a framework of stable and secure for everyone (citizens, various interest groups, business, etc.)

- $\quad$ Rules defining fair game and not taking their managing experience of developed countries: Modern state as a partner and as a guarantor.

- Continuation / deepening of the decentralization process as it ensures democracy, stability and promotes local economic development; It is also associated with financial decentralization process, at the same time strengthening the capacity of local units, training, and recognition of the positive experience in this area them;

- $\quad$ Building public private partnerships requires the focus of reforms and partnerships citizen - thus building a society with human face. Changing the mentality of local and central administration as part of public administration reform, promotion of cooperation among local units at home and abroad, including cross-border cooperation;

- Approximation of Albanian legislation with EU countries, and highlight the role of local government units in this process.

- Strengthening associations of local elected officials; institutionalization of relations with business and civil society, with laws and by laws.

\section{References}

[1] EBRD (2011) Albania, Assessment of the quality of PPP Legislation and of the effectiveness of its implementation

[2] Mitchell-Weaver, C. \& Manning, B. (1991). Public-Private Partnerships in Third World Development: A Conceptual Review. Studies in Comparative International Development..

[3] Osborne, S.P. (2000). Public-Private Partnerships: Theory and Practice in International Perspective. New York, Routledge,

[4] OECD. (2008). Public-Private Partnerships: in pursuit of risk sharing and value for money 
[5] Public-Private Partnerships National Experiences in the European Union, 10.02.2006; PE 369.858;

[6] World Bank (2014) Public-Private Partnerships Reference Guide version 2, World Bank Institute and PPIAF, Washington D.C.

[7] World Bank 2016 Public-Private Partnerships http://ppp.worldbank.org/public-privatepartnership/ overview

[8] Strategic Plan of Municipality of Korca. 